\title{
KNOWLEDGE, ATTITUDE AND PRACTICE ABOUT HYPERTENSION AMONG PEOPLE OF ABHA CITY SAUDI ARABIA
}

\section{MUNEER JAN, ABDULBARI AHMED ALZAHRANI, YAHYA MOHAMMED ALQAHTANI, ABDUSSALAM MOHAMMED A ALQHTANI, MOZOON MOHAMMED S ALQHTANI \& RAHAF KHALID ALQHTANI}

Assistant Professor, Department of Surgery, College of Medicine, King Khalid University, Saudi Arabia

\section{ABSTRACT \\ INTRODUCTION}

Hypertension (HTN) is characterized as blood pressure which is abnormally high. Hypertension is characterized as a systolic BP level of approximately $140 \mathrm{mmHg}$ and/or diastolic BP level of approximately $90 \mathrm{mmHg}$. Hypertension (HTN) is an significant public health issue for both developing and economically developed nations. According to the World Health Organization survey, in 2008, about $40 \%$ of people over 25 years of age had hypertension

\section{METHODS}

In this descriptive study, the data was gathered through validated questionnaire, Questionnaire composed on demographic questions, Knowledge, attitude and practices items about HTN

\section{RESULTS}

most of the respondents were living in Abha city (82.6\%),43.4\% belongs to the age group of 21-30, 28.1\% belongs to the age group of above $40.70 .1 \%$ were female while $29.9 \%$ were male. fair correlations between knowledge and attitude, knowledge and practice, attitude and practice scores, p-values were not significant

\section{CONCLUSION}

While patients had reasonably adequate information, attitude and experience about hypertension, they did need additional services, interventions to minimize all barriers associated with especially treatment-related barriers to uncontrolled hypertension. Findings suggest more research designed to find new successful methods for solving this problem.

KEYWORDS: Hypertension, Knowledge, Practice, Attitude \& Blood Pressure

Received: Jun 08, 2020; Accepted: Jun 28, 2020; Published: Sep 17, 2020; Paper Id.: IJMPERDJUN20201304

\section{INTRODUCTION}

Hypertension (HTN) is characterized as blood pressure which is abnormally high. Hypertension is characterized as a systolic BP level of approximately $140 \mathrm{mmHg}$ and/or diastolic BP level of approximately $90 \mathrm{mmHg}$. Hypertension (HTN) is an important public health problem in both economically developed and developing nations. According to the World Health Organization survey, in 2008, about $40 \%$ of people over 25 years of age had hypertension. Hypertension is a major risk factor for cardiovascular illness and mortality of all causes.

Hypertension is a major public health problem due to its high prevalence all around the globe. Around 7.5 million deaths or $12.8 \%$ of the total of all annual deaths worldwide occur due to HTN. It is predicted to be increased to 1.56 billion adults with hypertension in $2025 .^{1-6}$ 
Usually, hypertension itself does not present symptoms, and can remain undiagnosed for a long time. Also called hypertension is a silent killer disease which is often incidentally diagnosed. If a hypertensive patient remains untreated, it can lead to serious life-threatening complications of vital organs such as the brain, eye, heart, and kidney, resulting in death or serious patient death or serious patient disability ${ }^{7-12}$

In KSA, in crude terms the prevalence of hypertension was 26.1 per cent. Hypertension prevalence was 28.6 percent for males, while for females. The urban population showed a significantly higher prevalence of 27.9 per cent hypertension compared with the prevalence of 22.4 per cent of the rural population ${ }^{13}$

Hypertension is the chronic condition most prevalent and one of the most significant health conditions in the world. Ignorance of this condition can lead to a bad attitude which could potentially lead to an increased incidence of hypertension as the result of poor diet and lifestyle practice. ${ }^{14-15}$

Hypertension has been identified as a public health concern in both Saudi Arabia's rural and urban areas. In light of that, this study was conducted in Saudi Arabia's Abha region. The goal of this study was also to determine the awareness, attitude and practice (KAP) of hypertension among Abha residents / citizens in order to evaluate the connection between the KAP and to classify the factors associated with KAP regarding hypertension.

\section{METHODS}

In this descriptive study, the data was generated through validated questionnaire, Questionnaire composed on demographic questions, Knowledge, attitude and practices items about HTN. Convenience descriptive sampling method was adopted. Data was entered in the SPSS ver.20 for analysis. Descriptive statistics (Mean,S.D, frequency and percentages) were computed .Correlation test was also conducted. The duration of the study was January-2020 to April-2020. The ethical approval about the study was obtained from Research ethical committee (REC) of the college of medicine, KKU

\section{RESULTS}

Table 1 depicted that most of the respondents were living in Abha city (82.6\%),43.4\% belongs to the age group of 21-30, $28.1 \%$ belongs to the age group of above $40.70 .1 \%$ were female while $29.9 \%$ were male. $64.7 \%$ having an education level of high school. $97.0 \%$ were working in a health specialties. $48.8 \%$ were married, while $51.2 \%$ were un married.55.8\% were having less than 5000 SAR monthly income / month, while $61.9 \%$ have family history of hypertension, and almost $90.00 \%$ were nonsmoker. In table 2, 45.1\% have Opted the option (systolic" for top number and "diastolic" for bottom number),38.5\% agreed that both numbers are important. $70.7 \%$ agreed that people will able to lower their B.P.,88.4\% considering HTN as a source of other health problems. 93.6\% were agreed that it is important to maintain B.P level. In table 3 we have observed that $90.8 \%$ were agreed to reduce the salt in their diet.95.5\% were considering the importance of regular check of B.P. $95.5 \%$ were agreed that regular medication is important in hypertensive Patients. $97.7 \%$ agreed the role of exercise. Table 4 showed that $75.8 \%$ measured their B.P, only when they visited the physicians.38.5\% did not remember when they checked their B.P level.65.2\% hade normal B.P in their last visit. Table 5 illustrated that $91.5 \%$ were agreed that diet rich in salt causes hypertension,71.5\% agreed that smoking causes HTN $.81 .4 \%$ were in favor of that the obesity associated with hypertension. 94.1\% considering excersizez is a beneficial activity for HTN. Table 6 depicted that fair correlations between knowledge and attitude, knowledge and practice, attitude and practice scores, p-values were not significant . 
Table1: Demographic

\begin{tabular}{|c|c|c|}
\hline \multicolumn{3}{|c|}{ Are you living in Abha city? } \\
\hline & Frequency & Percent \\
\hline Yes & 603 & 82.6 \\
\hline No & 127 & 17.4 \\
\hline \multicolumn{3}{|c|}{ Age (Years) } \\
\hline$<20$ & 94 & 12.9 \\
\hline $21-30$ & 317 & 43.4 \\
\hline $31-40$ & 114 & 15.6 \\
\hline above 40 & 205 & 28.1 \\
\hline \multicolumn{3}{|c|}{ Gender } \\
\hline Male & 218 & 29.9 \\
\hline Female & 512 & 70.1 \\
\hline \multicolumn{3}{|c|}{ Educational Status } \\
\hline & Frequency & Percent \\
\hline Middle School & 220 & 29.9 \\
\hline High School & 472 & 64.7 \\
\hline College Graduate & 38 & 5.2 \\
\hline \multicolumn{3}{|c|}{ Do you Work or Study in a Health Specialties? } \\
\hline & Frequency & Percent \\
\hline Yes & 25 & 3.0 \\
\hline \multirow[t]{3}{*}{ No } & 705 & 97.0 \\
\hline & Marital Status & \\
\hline & Frequency & Percent \\
\hline Married & 356 & 48.8 \\
\hline Un Married & 374 & 51.2 \\
\hline \multicolumn{3}{|c|}{ Income (inSAR) } \\
\hline$<5000$ & 407 & 55.8 \\
\hline $5000-15000$ & 236 & 32.4 \\
\hline Above 15000 & 87 & 11.9 \\
\hline \multicolumn{3}{|c|}{ is there anyone of your family has hypertension? } \\
\hline Yes & 96 & 13.2 \\
\hline No & 634 & 86.9 \\
\hline \multicolumn{3}{|c|}{ Family History of Hypertension ( is there anyone of your Family has Hypertension } \\
\hline Yes & 452 & 61.9 \\
\hline No & 278 & 38.1 \\
\hline \multicolumn{3}{|c|}{ Smoking Status } \\
\hline & Frequency & Percent \\
\hline No Smoker & 663 & 90.8 \\
\hline X-smoker & 30 & 4.1 \\
\hline Current smoker & 37 & 5.1 \\
\hline
\end{tabular}

Table 2: Knowledge

\begin{tabular}{|c|c|c|}
\hline \multicolumn{3}{|c|}{ What does the two numbers reported for blood pressure mean? } \\
\hline & Frequency & Percent \\
\hline systolic" for top number and "diastolic"' for bottom number & 329 & 45.1 \\
\hline diastolic" for top number and "systolic"' for bottom number & 55 & 7.5 \\
\hline Don't know & 346 & 47.4 \\
\hline \multicolumn{3}{|l|}{ Which Measure(s) is (are) More Important? } \\
\hline Top & 100 & 13.7 \\
\hline Bottom & 69 & 9.5 \\
\hline Both & 281 & 38.5 \\
\hline Don't know & 280 & 38.4 \\
\hline \multicolumn{3}{|c|}{ Can People do things to Lower their Blood Pressure? } \\
\hline Yes & 516 & 70.7 \\
\hline
\end{tabular}


Muneer Jan, Abdulbari Ahmed Alzahrani, Yahya Mohammed Alqahtani, Abdussalam Mohammed A Alqhtani, Mozoon Mohammed S Alqhtani \& Rahaf Khalid Alqhtani

\begin{tabular}{|c|c|c|}
\hline No & 90 & 12.3 \\
\hline Don't know & 124 & 17.0 \\
\hline \multicolumn{3}{|c|}{ Can Hypertension lead to Problems to Kidney, Brain and Heart? } \\
\hline Yes & 645 & 88.4 \\
\hline No & 11 & 1.5 \\
\hline Don't know & 74 & 10.1 \\
\hline \multicolumn{3}{|c|}{ Is it Important to Maintain Blood Pressure with Normal Range? } \\
\hline Yes & 682 & 93.6 \\
\hline No & 20 & 2.7 \\
\hline Don't know & 28 & 3.8 \\
\hline
\end{tabular}

Table 3: Attitude

\begin{tabular}{|l|c|c|}
\hline \multicolumn{3}{|c|}{ Should we Reduce Salt Intake to Prevent Hypertension? } \\
\hline & Frequency & Percent \\
\hline Yes & 663 & 90.8 \\
\hline No & 53 & 7.3 \\
\hline Don't know & 14 & 1.9 \\
\hline
\end{tabular}

Do you think Regular Checking of your Blood Pressure Level is Important?

\begin{tabular}{|l|c|c|}
\hline Yes & 697 & 95.5 \\
\hline No & 18 & 2.5 \\
\hline Don't know & 15 & 2.1 \\
\hline
\end{tabular}

Do you think Regular Medication is Important in Hypertensive Patients ?

\begin{tabular}{|l|c|c|}
\hline Yes & 697 & 95.5 \\
\hline No & 11 & 1.5 \\
\hline Don't know & 22 & 3.0 \\
\hline
\end{tabular}

\begin{tabular}{|l|c|c|}
\hline \multicolumn{3}{|c|}{ Should we Exercise Regularly for Healthy Life? } \\
\hline & Frequency & Percent \\
\hline Yes & 713 & 97.7 \\
\hline No & 7 & 1.0 \\
\hline Don't know & 10 & 1.4 \\
\hline
\end{tabular}

Table 4: Practice

\begin{tabular}{|c|c|c|}
\hline \multicolumn{3}{|c|}{ How many time did you Measure your Blood Pressure? } \\
\hline & Frequency & Percent \\
\hline Daily & 345 & 4.7 \\
\hline Weekly & 89 & 12.2 \\
\hline Monthly & 54 & 7.4 \\
\hline Only when I visit a physician & 553 & 75.8 \\
\hline \multicolumn{3}{|c|}{ When was your Last visit with your Physician? } \\
\hline Last week & 109 & 14.7 \\
\hline Last month & 226 & 31.0 \\
\hline Last year & 114 & 15.6 \\
\hline I do not remember & 281 & 38.5 \\
\hline \multicolumn{3}{|c|}{ What was your Blood Pressure Level at your most Recent Visit ? } \\
\hline & Frequency & Percent \\
\hline $\mathrm{o}<100 /<70 \mathrm{mmHg}=$ & 67 & 9.2 \\
\hline $\mathrm{o}<120 /<80 \mathrm{mmHg}$ & 249 & 34.1 \\
\hline$<140 /<100 \mathrm{mmHg}$ & 78 & 10.7 \\
\hline o > $140 />100 \mathrm{mmHg}$ & 34 & 4.7 \\
\hline I do not remember & 302 & 41.4 \\
\hline \multicolumn{3}{|c|}{ If you remember, What did you think your blood pressure level was at this visit } \\
\hline & Frequency & Percent \\
\hline High & 81 & 11.1 \\
\hline Normal & 476 & 65.2 \\
\hline Low & 46 & 6.3 \\
\hline
\end{tabular}




\begin{tabular}{|l|c|c|}
\hline Do not know & 127 & 17.4 \\
\hline \multicolumn{2}{|c|}{ How many time do you do exercises ? } \\
\hline Daily & Frequency & Percent \\
\hline Weekly & 119 & 16.3 \\
\hline Monthly & 216 & 29.6 \\
\hline I do not excersize & 144 & 19.7 \\
\hline
\end{tabular}

Table 5: Causes of HTN

\begin{tabular}{|c|c|c|}
\hline \multicolumn{3}{|c|}{ Is the Diet Rich in salt causes Hypertension? } \\
\hline & Frequency & Percent \\
\hline Yes & 668 & 91.5 \\
\hline No & 35 & 4.8 \\
\hline Do not know & 27 & 3.7 \\
\hline \multicolumn{3}{|c|}{ Is the smoking major cause of hypertension? } \\
\hline & Frequency & Percent \\
\hline Yes & 522 & 71.5 \\
\hline No & 38 & 5.2 \\
\hline Do not know & 170 & 23.3 \\
\hline \multicolumn{3}{|c|}{ Is obesity associated with hypertension? } \\
\hline & Frequency & Percent \\
\hline Yes & 594 & 81.4 \\
\hline No & 52 & 7.1 \\
\hline Do not know & 84 & 11.5 \\
\hline \multicolumn{3}{|c|}{ Is exercise having beneficial role in hypertension } \\
\hline & Frequency & Percent \\
\hline Yes & 687 & 94.1 \\
\hline No & 13 & 1.8 \\
\hline Do not know & 30 & 4.1 \\
\hline
\end{tabular}

Table 6

\begin{tabular}{|l|c|c|c|}
\hline \multicolumn{3}{|c|}{ Correlation between Knowledge, attitude and practice: $\mathbf{r}(\mathbf{p})$} \\
\hline \multirow{2}{*}{ Knowledge } & Knowledge & Attitude & Practice \\
& & 0.34 & 0.29 \\
& & 0.62 & 0.54 \\
\hline \multirow{2}{*}{ Attitude } & 0.34 & & 0.39 \\
& 0.62 & & 0.69 \\
\hline \multirow{2}{*}{ Practice } & 0.29 & 0.39 & \\
& 0.54 & 0.69 & \\
\hline
\end{tabular}

\section{DISCUSSIONS}

Hypertension is one of the most common long-lasting diseases in many countries, and one of the most serious health conditions that cause death. One of the main reasons for HTN is a family history of high blood pressure. Most respondents accepted, in our report, that HTN is a major health problem. Most respondents accepted that Smoking is one of the main causes of HTN relative to other research. Which further associated with cardio, kidney, lungs and other disease .Our research is in support of other findings that have consistently shown exercise intervention results that moderate aerobic exercise reduces blood pressure in patients with mild to severe hypertension. Recent studies have also shown that exercise in treating patients with extreme hypertension and left ventricular hypertrophy is healthy and successful in further decreasing the blood pressure. The WHO strongly recommended reducing dietary salt intake as one of the top priority actions to address the global non-communicable disease crisis, and urged member nations to take action to reduce population-wide dietary salt intake to 
reduce hypertension, cardiovascular disease and stroke deaths. Some scientists, however, also recommend an increased risk of Obesity is a major risk for essential hypertension, diabetes and other morbidity. Growing obesity and the size of related health problems has significant repercussions for individuals and government health systems. Excessive overweight remains one of the most overlooked problems of public health worldwide, although obesity is associated with growing rates of injury, disease and death. Cardiovascular diseases, the world's leading cause of death, particularly hypertension and diabetes, are the major diseases associated with obesity, which are in line with our findings. ${ }^{16-22}$ Our analysis is consistent with Fakhri et al. No major differences were found between awareness, attitude and scores of practice ${ }^{12}$

\section{CONCLUSIONS}

While patients had reasonably adequate information, attitude and experience about hypertension, they did need additional services, interventions to minimize all barriers associated with especially treatment-related barriers to uncontrolled hypertension. Findings suggest more research designed to find new successful methods for solving this problem.

\section{REFERENCES}

1. Singh, S., Shankar, R., \& Singh, G. P. (2017). Prevalence and Associated Risk Factors of Hypertension: A Cross-Sectional Study in Urban Varanasi. International journal of hypertension, 2017, 5491838. https://doi.org/10.1155/2017/5491838

2. Erem C., Hacihasanoglu A., Kocak M., Deger O., Topbas M. Prevalence of prehypertension and hypertension and associated risk factors among Turkish adults: trabzon hypertension study. Journal of Public Health. 2009;31(1):47-58. doi: 10.1093/pubmed/fdn078. [PubMed] [CrossRef] [Google Scholar]

3. Ahmed A., Rahman M., Hasan R., et al. Hypertension and associated risk factors in some selected rural areas of Bangladesh. International Journal of Research in Medical Sciences. 2014;2(3):p. 925. doi: 10.5455/23206012.ijrms20140816. [CrossRef] [ Google Scholar]

4. Mishra C. P., Kumar S. Risk factors of hypertension in a rural area of Varanasi. Indian Journal of Preventive and Social Medicine. 2011;42(1):101-111. [Google Scholar]

5. Abebe S. M., Berhane Y., Worku A., Getachew A. Prevalence and associated factors of hypertension: a crossectional community based study in Northwest Ethiopia. PLoS ONE. 2015;10(4) doi: 10.1371/journal.pone.0125210.e0125210 [PMC free article] [ㅁuMed] [ㄷossRef] [Google Scholar]

6. Mendis S. World Health Organisation; 2010. Global status report on noncommunicable diseases 2010. http://www.who.int/nmh/publications/ncd_report2010/en/ [Google Scholar]

7. Buang, N., Rahman, N., \&Haque, M. (2019). Knowledge, attitude and practice regarding hypertension among residents in a housing area in Selangor, Malaysia. Medicine and pharmacy reports, 92(2), 145-152. https://doi.org/10.15386/mpr-1227

8. Eshkoor SA, Hamid TA, Shahar S, $\mathrm{Ng}$ CK, Mun CY. Factors Affecting Hypertension among the Malaysian Elderly. J CardiovasDev Dis. 2016;3(1) [Mㄷ free article] [ㅁubMed] [ Google Scholar]

9. 13. Alefan Q, Ibrahim MIM, Razak TA, Ayub A. Cost of treating hypertension in Malaysia. Asian J Pharm Clin Res. 2009;2:15. [Google Scholar]

10. Naing C, Yeoh PN, Wai VN, Win NN, Kuan LP, Aung K. Hypertension in Malaysia: An Analysis of Trends from the National Surveys 1996 to 2011. Medicine. 2016;95:e2417. [PMC free article] [PubMed] [Google Scholar]

11. National Heart, Lung, and Blood Institute. High Blood Pressure Also known as Hypertension. 2018. Available at https://www.nhlbi.nih.gov/health-topics/high-blood-pressure. 
12. Sabouhi F, Babaee S, Naji H, Zadeh AH. Knowledge, awareness, attitudes and practice about hypertension in hypertensive patients referring to public health care centers in Khoor\&Biabanak. Iran J Nurs Midwifery Res. 2011;16:34-40. [PMC free article] [ㅁuMed] [ Google Scholar]

13. Al-Nozha MM, Abdullah M, Arafah MR, Khalil MZ, Khan NB, Al-Mazrou YY, Al-Maatouq MA, Al-Marzouki K, Al-Khadra A, Nouh MS, Al-Harthi SS, Al-Shahid MS, Al-Mobeireek A. Hypertension in Saudi Arabia. Saudi Med J. 2007 Jan;28(1) 77-84. PMID: 17206295 .

14. Jarari N, Rao N, Peela JR, Ellafi KA, Shakila S, Said AR, et al. A review on prescribing patterns of antihypertensive drugs. ClinHypertens. 2016;22:7. [프 free article] [PubMed] [ [ Google Scholar]

15. . Ramli A, Ahmad NS, Paraidathathu T. Medication adherence among hypertensive patients of primary health clinics in

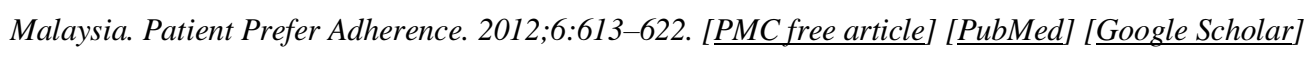

16. Jiang, S. Z., Lu, W., Zong, X. F., Ruan, H. Y., \& Liu, Y. (2016). Obesity and hypertension. Experimental and therapeutic medicine, 12(4), 2395-2399. https://doi.org/10.3892/etm.2016.3667

17. Kitahara CM, Flint AJ, de Gonzalez A Berrington, Bernstein L, Brotzman M, MacInnis RJ, Moore SC, Robien K, Rosenberg PS, Singh PN, et al. Association between class III obesity (BMI of 40-59 kg/ $\mathrm{m}^{2}$ ) and mortality: A pooled analysis of 20 prospective

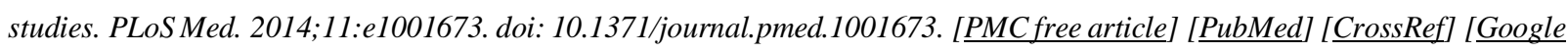
Scholar]

18. Gill T, King L, Caterson I. Obesity prevention: Necessary and possible A structured approach for effective planning. ProcNutr Soc. 2005;64:255-261. doi: 10.1079/PNS2005425. [PubMed] [CrossRef] [Google Scholar]

19. O'Connor DW. The impact of obesity on national and homeland security. Naval Postgraduate School; Monterey, CA: 2013. [Google Scholar]

20. Murray CJ, Lopez AD. Mortality by cause for eight regions of the world: Global Burden of Disease Study. Lancet. 1997;349:1269-1276. doi: 10.1016/S0140-6736(96)07493-4. [ㅁubed] [CrossRef] [Google Scholar]

21. Strumpf E. The obesity epidemic in the United States: causes and extent, risks and solutions. The Commonwealth Fund; New York, NY: 2004. [PubMed] [Google Scholar]

22. Hall JE, Crook ED, Jones DW, Wofford MR, Dubbert PM. Mechanisms of obesity-associated cardiovascular and renal disease. Am J Med Sci. 2002;324:127-137. doi: 10.1097/00000441-200209000-00003. [ㅁubMed] [CrossRef] [ㅁoogle Scholar] 
